\title{
Impact of microfluidization on colloidal properties of insoluble pea protein fractions
}

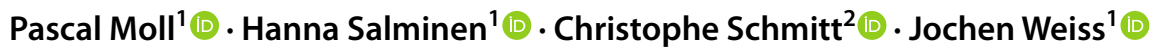

Received: 28 July 2020 / Revised: 30 September 2020 / Accepted: 3 October 2020 / Published online: 6 February 2021

(c) The Author(s) 2021

\begin{abstract}
Microfluidization is a technique commonly used to disrupt and homogenize dispersions such as oil-in-water emulsions or cellular suspensions. In this study, we investigated its ability to alter the physicochemical properties of plant-derived insoluble protein aggregates such as those found in pea protein extracts. Insoluble pea protein dispersions $(5 \% \mathrm{w} / \mathrm{w}, \mathrm{pH} 7)$ were homogenized at 25-150 MPa for 1-5 cycles. Increasing the homogenization pressure and cycles decreased the particle size $\left(d_{43}\right)$ of the unhomogenized insoluble pea proteins from $180 \pm 40 \mu \mathrm{m}$ to $0.2 \pm 0.0 \mu \mathrm{m}$ (at $\geq 125 \mathrm{MPa}$ ), leading to more transparent dispersions. Furthermore, the solubility of the insoluble pea proteins increased from $23 \pm 1 \%$ to $86 \pm 4 \%$. Treatments with chaotropic agents, dithiothreitol and urea, revealed that insoluble pea protein aggregates were stabilized not only by disulphide bonds but also by hydrogen bonds and hydrophobic interactions. These molecular interactions were disrupted by microfluidization. The study provides insights into the disruption mechanism of insoluble pea proteins by applying microfluidization and offers a mean to improve their technofunctional properties to facilitate further use in food manufacture.
\end{abstract}

Keywords Insoluble pea protein $\cdot$ Microfluidization $\cdot$ Solubility $\cdot$ Hydrogen bonds $\cdot$ Hydrophobic interactions $\cdot$ Disulphide bonds

\section{Introduction}

Pea (Pisum sativum L.) proteins can potentially replace conventional animal-derived proteins (e.g. whey, egg white) in many food applications due to its lower cost, commercial availability, low environmental footprint, lower allergenicity, and good nutritional value [1]. The salt-soluble globulins make up for $70-80 \%$ of total pea proteins. They comprise hexameric legumins (11S, 300-400 kDa), trimeric vicilins (7S, $\sim 150-180 \mathrm{kDa}$ ), and convicilins (7S, $290 \mathrm{kDa}$ ) consisting of $\sim 20$ and $\sim 40 \mathrm{kDa}, \sim 30-50 \mathrm{kDa}$, and $\sim 70 \mathrm{kDa}$ subunits, respectively. Water-soluble albumins $(\sim 5-80 \mathrm{kDa})$ account for 10-20\% of the total pea proteins [2-4]. Usually, pea proteins show limited techno-functionality compared to

Jochen Weiss

j.weiss@uni-hohenheim.de

1 Department of Food Material Science, Institute of Food Science and Biotechnology, University of Hohenheim, Garbenstrasse 25, 70599 Stuttgart, Germany

2 Nestlé Research, Department of Chemistry, Nestlé Institute of Material Sciences, Vers-chez-les-Blancs, CH-1000 Lausanne 26, Switzerland conventional proteins, attributed to their low intrinsic water solubility and structural state $[1,5]$. The structural state of the pea proteins is influenced by purification methods and temperature exposure during drying. For example, pea proteins obtained by ultrafiltration processes had a higher techno-functionality compared to heat-, acid-, and heat-acidprecipitation possibly due to the preservation of their native state [6]. Furthermore, protein folding can be prevented by applying spray drying at temperatures below the denaturation temperature of the pea proteins $\left(\mathrm{T}_{\mathrm{d}} \approx 85^{\circ} \mathrm{C}\right)$ or freeze drying [7]. Therefore, the used processing technique is of key importance in retaining or modifying the functionality of pea proteins.

Homogenization is a non-thermal processing technology, in which a fluid is forced through a small gap or channels by means of high pressure resulting in a more homogeneous size distribution of particles in the fluid [8]. Disruption of the particles is achieved by the combined action of turbulence, shear force, and cavitation as well as impingement on the walls and fluid jet collisions. The magnitude of fragmentation depends on the design of the respective device [9]. For example, a microfluidizer equipped with an interaction chamber contains microchannels forcing the fluid streams to 
collide in an impact zone, whereas in a valve homogenizer, disruption occurs due to stress fluctuations and cavitation [10].

In the food industry, homogenization is used to emulsify oil droplets, disrupt particles, modify structures, and extract metabolites through cell disruption as well as inactivate microorganisms and enzymes [8, 9]. In the case of proteins with inferior functionalities, structural modifications are of great interest as they may impart changes in their physicochemical properties, thus potentially improving the proteins' techno-functionality [11]. The modifications of proteins can be attributed to (1) particle size changes and (2) alterations in their structure, both depending on the applied homogenization parameters and the used proteinaceous material $[12,13]$. For example, microfluidized pea protein emulsions showed a higher stability compared to ultrasonication as a result of smaller particle size and higher hydrophobicity [14]. Recently, microfluidization was applied to pea albumin aggregates to modulate their foaming properties [15]. Although homogenization is a well-established processing operation in dairy, juice, pharmaceutical, and chemical manufacturing, the molecular disruption mechanism of aggregates is still largely unknown compared to droplet breakup. For example, shear forces lead to droplet elongation and ultimately droplet break-up, whereas they seem to have little impact on rigid particles such as protein aggregates [10]. Bałdyga et al. [16] reported a more effective break-up of aggregates using a high-pressure system compared to a rotor-stator system due to the fact that cavitation occurs in the former in addition to hydrodynamic stresses.

Proteins and protein aggregates are stabilized by hydrophobic and electrostatic interactions as well as hydrogen and disulphide bonds [17] that are prone to changes upon applied processing conditions. For example, disulphide bonds can be formed at high pressures, elevated temperatures or upon shear, whereas electrostatic and hydrophobic interactions are disrupted by pressure $[18,19]$. Hydrogen bonds were reported to be insensitive to pressure [20]. This suggests that some molecular interactions can be manipulated by applying high pressures during microfluidization.

The aim of this study was to investigate the impact of high-pressure homogenization via microfluidization on insoluble pea protein aggregates. We hypothesized that an increase in microfluidization pressure and cycles increasingly disrupts electrostatic and hydrophobic interactions keeping protein aggregates together, leading to an overall weakening of protein-protein interactions and thus facilitating a breakup of aggregates. Furthermore, disulphide bonds should remain unaffected as the pressures used in this study were chosen to be below $600 \mathrm{MPa}$, which was reported to be a critical stress level for disulphide bond-induced aggregation of other proteins such as egg white [20]. We postulated that microfluidization may result in reduced particle sizes, which in turn will increase the solubility of the chosen protein.

\section{Materials and methods}

\section{Materials}

Pea protein isolate powder (Pisane C9; dry matter 95.7\%, protein content $66.9 \% \mathrm{~N} \times 5.36$ ) was manufactured by Cosucra (Warcoing, Belgium). According to the manufacturer, the product was extracted from yellow dry peas in a wet process. The peas were first dehulled, milled, and solubilized in water. Then, the soluble (protein) and insoluble (fiber and starch) fractions were separated in a decantation step. Next, the soluble protein fraction was pasteurized, purified, and concentrated, and finally spray dried, resulting in a denatured protein product. Hydrochloric acid, magnesium acetate, petroleum ether, and urea were purchased from Carl Roth GmbH \& Co. KG (Karlsruhe, Germany). Dithiothreitol (DTT) was purchased from AppliChem GmbH (Darmstadt, Germany). Double distilled water was used as solvent for all experiments.

\section{Fractionization of pea protein isolate}

Pea protein isolate $(5 \% \mathrm{w} / \mathrm{w})$ was dissolved in water and stirred overnight at $2-5{ }^{\circ} \mathrm{C}$ to ensure full hydration. The dispersion was then centrifuged at $16.000 \mathrm{~g}$ for $30 \mathrm{~min}$ at $2-5{ }^{\circ} \mathrm{C}$ (Avanti J-30I, Beckman Coulter, Krefeld, Germany). The supernatant containing the soluble proteins was separated from the pellet comprising the insoluble proteins. Next, the pellet was freeze-dried (Sublimator 15, Zirbus technology, Bad Grund, Germany) and ground to obtain a powder (="insoluble pea proteins").

\section{Chemical analyses of the proteins}

The dry matter and ash content were determined gravimetrically according to AS § 64 LFGB 06.00-3, and AS § 64 LFGB $06.00-4$, respectively [21]. The fat content was analysed according to AS § 64 LFGB 06.00-6 [21]. The protein content was quantified according to the Dumas method [22] using a rapid nitrogen analyzer (Dumatherm N Pro, Gerhardt GmbH \& Co. KG, Königswinter, Germany). A nitrogen-toprotein conversion factor of $\mathrm{N} \times 5.36$ was used [23].

\section{Microfluidization of insoluble pea proteins}

Insoluble pea proteins $(5 \% \mathrm{w} / \mathrm{w}$ freeze-dried powder) were hydrated in water by stirring overnight at $2-5^{\circ} \mathrm{C}$, and then adjusted to $\mathrm{pH} 7$ with $6 \mathrm{M} \mathrm{HCl}$. The microfluidization of the insoluble pea protein dispersions was carried out with a LM10 
Microfluidizer equipped with an interaction chamber G10Z with a diameter of $87 \mu \mathrm{m}$ (Microfluidics Corp., Westwood, MA, USA) at six different pressures $(25,50,75,100,125$, and $150 \mathrm{MPa}$ ) using 1,3 , and 5 cycles. The temperature at the outlet was kept below $25^{\circ} \mathrm{C}$ by cooling the interaction chamber and the attached coil with ice water. A non-microfluidized dispersion of insoluble pea proteins served as a control.

\section{Effect of chaotropic reagents}

Non-microfluidized and microfluidized (50 MPa, 3 cycles) insoluble pea proteins $(5 \% \mathrm{w} / \mathrm{w}$ freeze-dried powder in water, $\mathrm{pH} 7$ ) were subjected to chaotropic reagents urea and DTT. For this, aqueous stock solutions of urea (15 M) and DTT $(30 \mathrm{mM})$ were prepared and adjusted to $\mathrm{pH} 7$ with $6 \mathrm{M} \mathrm{HCl}$ or $6 \mathrm{M} \mathrm{NaOH}$. The protein dispersion had a final concentration of $5 \mathrm{M}$ urea, or $10 \mathrm{mM}$ DTT. The dispersions were stirred for $24 \mathrm{~h}$ at $2-5^{\circ} \mathrm{C}$ before particle size and turbidity analyses. Samples with no added chaotropic agents served as control.

\section{Particle size}

Static light scattering (Horiba LA-950, Retsch Technology, Haan, Germany) was used to determine the mean surface $\left(d_{32}\right)$ and volume $\left(d_{43}\right)$ diameters of the samples. The refractive indices were set to 1.33 for the aqueous phase and 1.52 for the dispersed pea protein phase. The samples were diluted with $\mathrm{pH}$-adjusted water to prevent multiple scattering effects. In the case of chaotropic agents, $5 \mathrm{M}$ urea or $10 \mathrm{mM}$ DTT solutions were used for dilution. The refractive index for the aqueous phase with $5 \mathrm{M}$ urea was set to 1.37 and 1.33 for $10 \mathrm{mM} \mathrm{DTT.}$

\section{Z-Potential}

Electrophoretic light scattering (Zetasizer Nano-ZS, Malvern Instruments, Malvern, UK) was applied to determine the $\zeta$-potential of samples at $25{ }^{\circ} \mathrm{C}$. The samples were diluted to $0.1 \%(\mathrm{w} / \mathrm{w})$ with appropriate $\mathrm{pH}$-adjusted water.

\section{Turbidity}

The absorbance $(A)$ of the samples was determined in a $1 \mathrm{~cm}$ path-length polystyrene cuvette (PS macro, VWR, Darmstadt, Germany) using a UV/Visible spectrophotometer (model 8453 , Hewlett Packard, Palo Alto, USA) at $630 \mathrm{~nm}$. The samples were diluted to $0.1 \%(\mathrm{w} / \mathrm{w})$ with appropriate $\mathrm{pH}$-adjusted water. Turbidity $(T)$ was calculated with Eq. 1:

$T=2.303 \times A \times L^{-1}$,

where $L$ is the path length of the cuvette $(\mathrm{cm})$. Bidistilled water and in case of chaotropic agent measurements $5 \mathrm{M}$ urea or $10 \mathrm{mM}$ DTT solution served as a blank.

\section{Microstructure and visual observation}

The microstructure of the samples was visualized by an Axio Scope.A1 optical light microscope mounted with A-Plan 40x/0.65 Ph2 objective equipped with an AxioCam ICc3 digital camera (Carl Zeiss, Jena, Germany). In addition, photographic images for visual observation were taken.

\section{Solubility}

The microfluidized and non-microfluidized insoluble pea protein dispersions (5\% freeze-dried powder) were centrifuged at $16.000 \mathrm{~g}$ for $30 \mathrm{~min}$ at $2-5^{\circ} \mathrm{C}(\mathrm{Z} 32 \mathrm{HK}$, Hermle Labortechnik, Wehingen, Germany). The nitrogen content of the supernatant was analysed according to the Dumas method [22] as described above. The protein solubility $(S)$ was calculated with Eq. 2:

$S=\frac{\text { Nitrogen }_{\text {supernatant }}}{\text { Nitrogen }_{\text {dispersion }}} \times 100 \%$.

The freeze-dried powder contained $71.35 \%$ protein, and therefore the protein content in the sample was $3.57 \%$.

\section{Statistics}

All experiments were done in triplicates with three measurements. The results are expressed as mean and standard deviation. ANOVA and Tukey's post hoc test with a confidence interval of $95 \%$ was used to evaluate statistical differences (SPSS Statistics 25, IBM, New York, NY, USA). A regression analysis was carried out to assess a correlation between microfluidization and particle size reduction.

\section{Results and discussion}

\section{Characterization of insoluble pea proteins}

The fractionated and freeze-dried insoluble pea protein powder contained $71.35 \pm 0.79 \%$ protein, $4.18 \pm 0.24 \%$ water, $3.00 \pm 0.02 \%$ ash, and $0.45 \pm 0.07 \%$ fat. Pea protein isolates can also contain a substantial amount of carbohydrates and crude fibre, which might account for the remaining solids [24]. For example, starch $(50.8 \%)$ was found to be the main solid residue in pea flour [25]. Pectin is mainly found in pea hulls [26]. As the peas were dehulled during the manufacturing process of the pea protein isolate, the pectin content should be negligible. This indicates that the negatively charged pectin fibers are unlikely to contribute 
to aggregation of insoluble pea proteins via electrostatic interactions.

\section{Influence of homogenization on particle characteristics of insoluble pea proteins}

Initially, we evaluated the influence of microfluidization pressure (25-150 MPa) and number of applied cycles (1-5) on the particle size, turbidity, microstructure, and charge of the insoluble pea protein dispersions $(5 \% \mathrm{w} / \mathrm{w}$, $\mathrm{pH} 7$ ). The non-microfluidized insoluble pea proteins had a mean surface diameter $\left(d_{32}\right)$ of $73 \pm 11 \mu \mathrm{m}$ (Fig. 1a), and a mean volume diameter $\left(d_{43}\right)$ of $180 \pm 40 \mu \mathrm{m}$ (Fig. 1b), and showed a broad particle size $\left(d_{43}\right)$ distribution ranging between 10 and $1000 \mu \mathrm{m}$ (Fig. 2). Increasing the microfluidization pressure and the number of cycles led to a decrease in the particle sizes (Fig. 1). The mildest microfluidization condition used ( $25 \mathrm{MPa}, 1$ cycle) decreased the mean $d_{32}$ value of the insoluble pea proteins to $0.28 \pm 0.06 \mu \mathrm{m}$ (Fig. 1a). However, the mean volume particle size $\left(d_{43}=20 \pm 10 \mu \mathrm{m}\right)$ (Fig. 1b) and the particle size distribution data indicated that the sample still contained a significant fraction of protein aggregates between 1 and $100 \mu \mathrm{m}$ (Fig. 2). The harshest microfluidization condition used (150 MPa, 5 cycles) led to the formation of very small protein particles $\left(d_{32}=0.12 \pm 0.00 \mu \mathrm{m}\right.$; $\left.d_{43}=0.17 \pm 0.03 \mu \mathrm{m}\right)($ Fig. 1) with monomodally

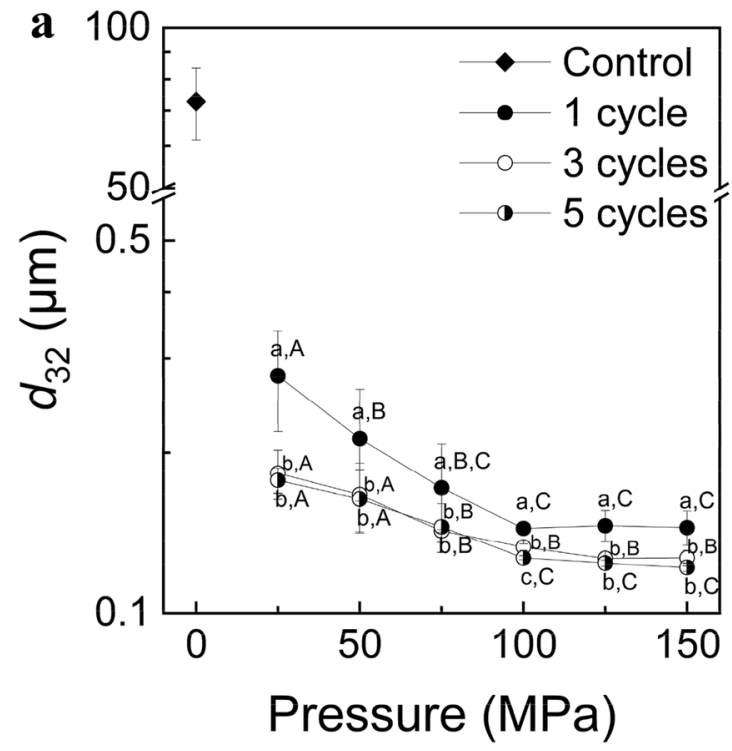

Fig. 1 Mean surface diameter $d_{32}$ (a) and volume diameter $d_{43}(\mathbf{b})$ of aqueous insoluble pea proteins $(5 \% \mathrm{w} / \mathrm{w}, \mathrm{pH} 7)$ after different microfluidization treatments. Control refers to a non-microfluidized sam-

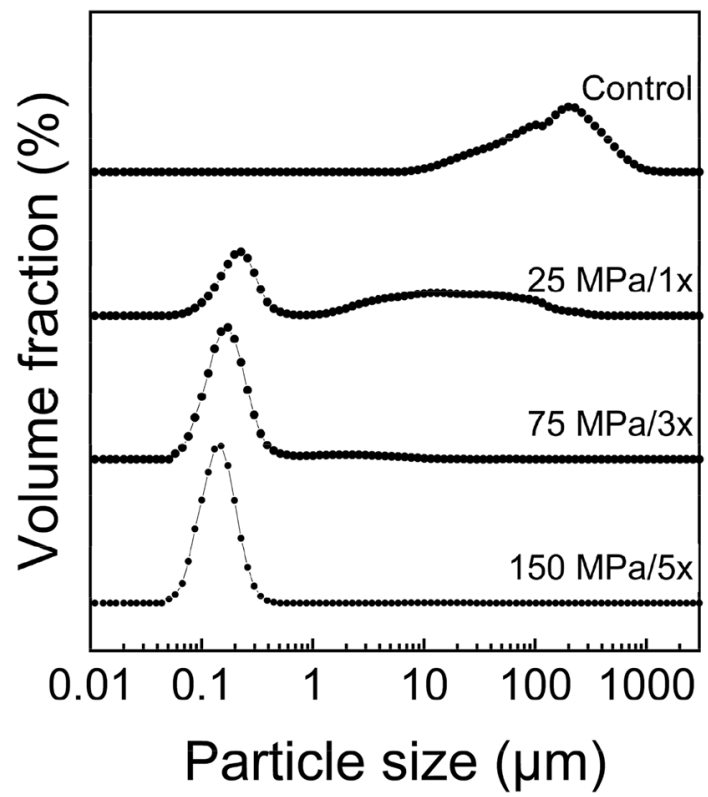

Fig. 2 Particle size $\left(d_{43}\right)$ distribution of aqueous insoluble pea proteins $(5 \% \mathrm{w} / \mathrm{w}, \mathrm{pH} 7)$ after different microfluidization treatments. Control refers to a non-microfluidized sample

distributed particles (Fig. 2). Similarly, small particle sizes $\left(d_{32}=0.12 \pm 0.00 \mu \mathrm{m} ; d_{43}=0.15 \pm 0.01 \mu \mathrm{m}\right)$ were obtained already at $125 \mathrm{MPa}$ (5 cycles) (Fig. 1). A regression

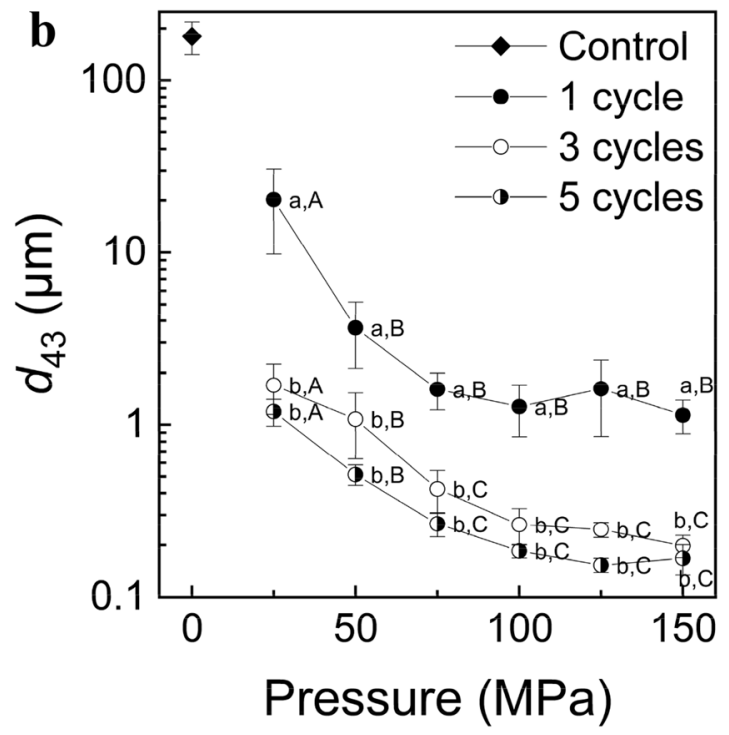

ple. Different small and capital letters denote a statistical difference $(p<0.05)$ within each pressure (impact of cycles) and within each cycle (impact of pressure), respectively 
analysis, plotted in a logarithmic (log) scale, showed a high coefficient of determination $\left(R^{2}\right)$ for all microfluidization cycles:

- 1 cycle: $\log \left(d_{43}\right)=-1.555 \times \log (\mathrm{P})+3.320 ; R^{2}=0.888$; $r=-0.942$

- 3 cycles: $\log \left(d_{43}\right)=-1.296 \times \log (\mathrm{P})+2.094 ; R^{2}=0.957$; $r=-0.978$

- 5 cycles: $\log \left(d_{43}\right)=-1.193 \times \log (\mathrm{P})+1.718 ; R^{2}=0.967$; $r=-0.984$

The correlation coefficients $(r)$ are evidence for a strong negative correlation between the microfluidization pressure and the mean volume diameter. The dissociation of insoluble protein aggregates into so-called supramolecular aggregates with sizes $<1 \mu \mathrm{m}$ upon homogenization has also been reported for faba bean protein $\left(\mathrm{d}_{H}=12 \mathrm{~nm}\right.$ with detected particles up to $100 \mathrm{~nm}, p=103 \mathrm{MPa}$ for 6 cycles, $\mathrm{pH} 7$ ) [27] and soy protein isolate $\left(\mathrm{d}_{H}=136 \mathrm{~nm}, p=207 \mathrm{MPa}\right.$ for 30 cycles, pH unknown) [28]. Djemaoune et al. [15] were able to decrease the hydrodynamic diameter of thermal pea albumin aggregates from 370 to $133 \mathrm{~nm}(p=130 \mathrm{MPa}$ for 3 passes, $\mathrm{pH}$ unknown).

Turbidity is a function of particle size, concentration, and polydispersity [29]. The turbidity measurements showed that increasing the microfluidization pressure and applied cycles led to a decrease in turbidity (Fig. 3). The non-microfluidized insoluble pea proteins $(=$ control) had the highest turbidity of $1.80 \pm 0.40 \mathrm{~cm}^{-1}$, whereas the lowest turbidity of $0.24 \pm 0.04 \mathrm{~cm}^{-1}$ was measured for insoluble pea proteins after microfluidization at $150 \mathrm{MPa}$ with five cycles. Microfluidization led to a substantial amount of particles having sizes of less than $1 \mu \mathrm{m}$ (Figs. 1, 2), which are the dominant particles for light scattering [30]. Consequently, these smaller particles scattered less light. In laser diffraction applying the Mie scattering theory, particles $<20 \mu \mathrm{m}$ scatter light at a relatively low intensity and at wide angles, whereas larger particles scatter light at relatively high intensity and low angles. The statistical analyses showed that both increasing the microfluidization pressure and increasing the applied cycles contributed to turbidity decrease $(p<0.05)$ (Fig. 3).

Furthermore, the particle size and size distribution (Figs. 1, 2) as well as turbidity (Fig. 3) measurements corresponded well with the optical microscopy images (Fig. 4a): the non-microfluidized insoluble pea proteins contained large, irregularly shaped protein aggregates,

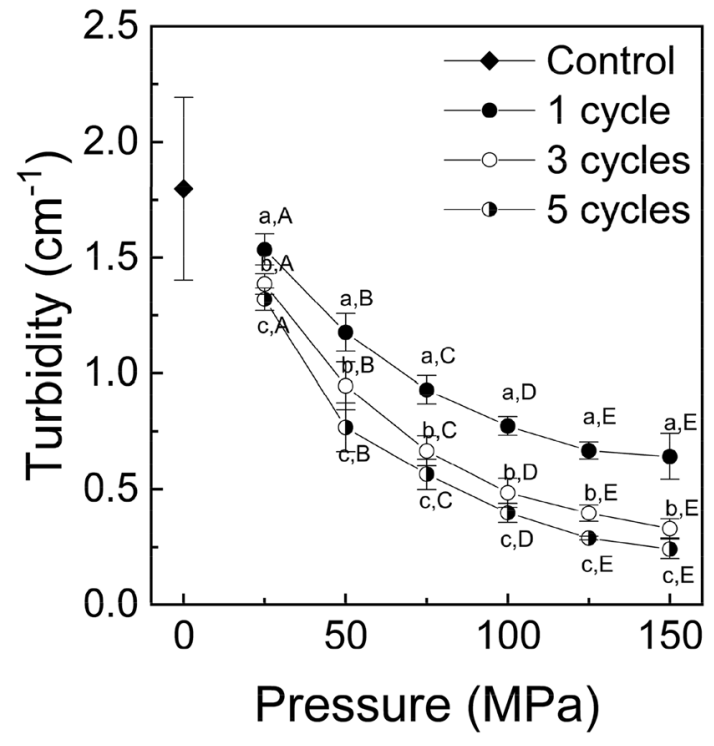

Fig. 3 Turbidity of aqueous insoluble pea proteins $(0.1 \% \mathrm{w} / \mathrm{w}, \mathrm{pH} 7)$ after different microfluidization treatments. Control refers to a nonmicrofluidized sample. Different small and capital letters denote a statistical difference $(p<0.05)$ within each pressure (impact of cycles) and within each cycle (impact of pressure), respectively

whereas increasing the microfluidization pressure yielded suspensions that contained only very few visible particles. Furthermore, the non-microfluidized insoluble pea protein dispersion exhibited a noticeable sedimentation after $24 \mathrm{~h}$ since the large protein aggregates were prone to gravitational separation, whereas the microfluidized samples did not form any distinct sedimented layers (Fig. 4b).

The net charges $(\zeta=-35.5 \pm 0.4 \mathrm{mV})$ of the insoluble pea protein dispersions were statistically independent of the microfluidization treatments. The high negative charges may have been sufficient in suppressing aggregation between the protein particles via electrostatic repulsion after microfluidization. Our results are in contrast to a study on soy protein isolate $(7 \% \mathrm{w} / \mathrm{w}, \mathrm{pH}$ not indicated), whose net charge decreased from approximately -16 to $-26 \mathrm{mV}$ after microfluidization at $207 \mathrm{MPa}$ with 30 cycles [28]. The authors, however, did not give any explanation for this change.

\section{Impact of homogenization on solubility of insoluble pea proteins}

In this part, we investigated the impact of microfluidization on the (nitrogen) solubility of the insoluble pea proteins 


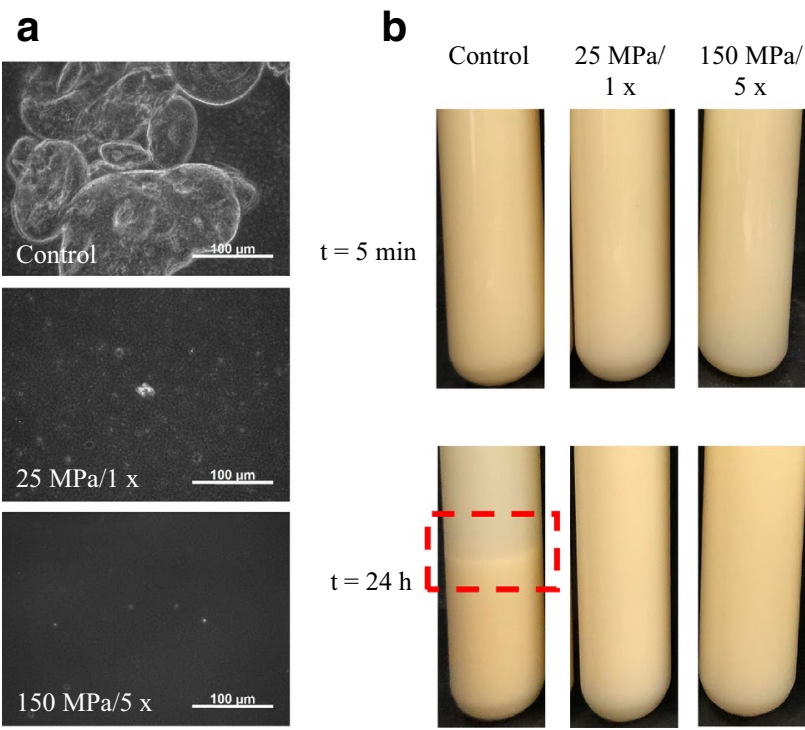

Fig. 4 Optical microscopy (a) and test tube images (b) of aqueous insoluble pea proteins $(5 \% \mathrm{w} / \mathrm{w}, \mathrm{pH} 7)$ after different microfluidization treatments. Control refers to a non-microfluidized sample. Rectangle indicates sedimentation

(5\% w/w, pH 7). Surprisingly, the non-microfluidized protein dispersion had some solubility $(22.6 \pm 1.3 \%)$ despite being separated as pellet after centrifugation. It is possible that the hydration overnight was not sufficient to fully solubilize all the proteins, or the separation via centrifugation and decanting did not fully remove all the soluble proteins. Furthermore, freeze-drying and grinding afterwards may have led to rearrangements in the protein aggregates, thus making them accessible for solubilization. The solubility of the insoluble pea proteins increased with increasing the microfluidization pressure and cycles $(p<0.05)$ (Fig. 5). For example, applying a pressure of $150 \mathrm{MPa}$ with five cycles increased the solubility to $86.3 \pm 4.4 \%$. This is in accordance with a previous study reporting a solubility increase from 35 to $99 \%$ upon homogenization for faba bean proteins (1\% w/w, pH 7, $103 \mathrm{MPa}, 6$ cycles) [27]. Chen et al. [31] speculated that dissociation of large protein aggregates into smaller particles leads to more protein-water interactions. This potentially improves protein hydration and subsequent dissolution. On the other hand, microfluidization treatment can potentially lead to protein denaturation uncovering hydrophobic groups, which were buried in the interior before, resulting in the formation of larger aggregates and decreased protein solubility [32]. This was the case in a study on soy flour proteins (13\% w/w, pH not indicated) whose solubility decreased from $39.1 \%$ (control) to $17.6 \%$ after homogenization at $150 \mathrm{MPa}$ with three cycles [32]. However, we did not observe any decrease in solubility upon homogenization treatment (Fig. 5). This can be explained by the fact that the initial pea protein isolate was already denatured as was confirmed by the manufacturer.

\section{Molecular interactions in insoluble pea protein aggregates}

In this series of experiments, we investigated the role of different intermolecular interactions stabilizing insoluble pea protein aggregates $(5 \% \mathrm{w} / \mathrm{w}, \mathrm{pH} 7)$ and the impact of intermediate microfluidization conditions $(50 \mathrm{MPa}$, three cycles) on those. These conditions were chosen as they were sufficient to cause a significant decrease in the particle size compared to the non-microfluidized proteins (Fig. 1), but still contained larger particles for potential disruption by the chaotropic agents. For this, we used urea, which is known to disrupt hydrophobic interactions and hydrogen bonds, and DTT, which reduces intra- and intermolecular disulphide bonds [33].

\section{Intermolecular interactions before microfluidization}

Upon addition of urea, the mean particle sizes $\left(d_{32}, d_{43}\right)$ of the non-microfluidized insoluble pea proteins decreased significantly $(p<0.05)$ (Table 1$)$. The particle size $\left(d_{32}\right)$ distribution data showed that the insoluble pea proteins after urea treatment were still highly polydisperse with sizes ranging from 10 to $400 \mu \mathrm{m}$ (Fig. 6). However, less particles with sizes $>200 \mu \mathrm{m}$ were present compared to the control. The addition of urea disrupted the large aggregates into a higher number of smaller aggregates (Fig. 6). Therefore, more particles that scatter light were present, which is the reason for the slight turbidity increase compared to the control sample (no chaotropic agent) (Table 1). These results indicate that hydrophobic interactions and hydrogen bonds partially stabilized insoluble pea protein aggregates. The dissolution of protein aggregates upon urea addition was also found for microalga Chlorella protothecoides [34]. Purification methods and subsequent drying can potentially lead to structural rearrangement of the proteins, resulting in increased surface hydrophobicity [35]. Oliete et al. [7] reported that pea globulin flocculation in undiluted sample conditions $(5 \% \mathrm{w} / \mathrm{w}, \mathrm{pH} 7.2)$ was driven by hydrogen bonds.

Similarly, the addition of DTT into the insoluble pea protein dispersion also decreased the mean particle sizes $\left(d_{32}, d_{43}\right)$ (Table 1$)$, however, the particles remained 


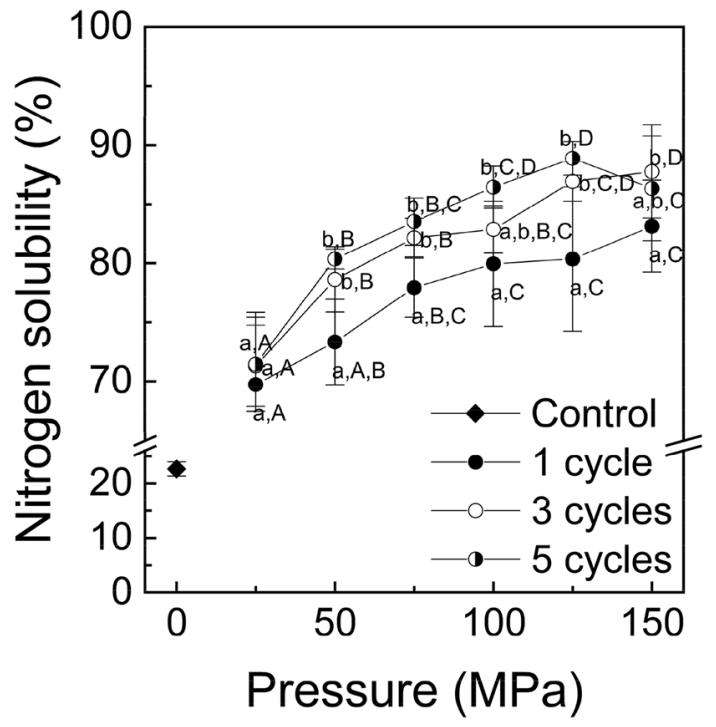

Fig. 5 Nitrogen solubility of insoluble pea proteins (5\% w/w, $\mathrm{pH} 7$ ) after different microfluidization treatments. Control refers to a nonmicrofluidized sample. Different small and capital letters denote a statistical difference $(p<0.05)$ within each pressure (impact of cycles) and within each cycle (impact of pressure), respectively

polydisperse $\left(d_{32}=6-400 \mu \mathrm{m}\right)$ (Fig. 6). The turbidity increased significantly (Table 1) because of an increase in scattering particles. These data demonstrate that the insoluble pea protein aggregates are interlinked also by disulphide bonds. Previously, disulphide bonds were shown to be the main contributors in stabilising extruded pea protein isolates [36]. Extrusion employs the combination of not only pressure and shear but also high temperatures that can induce formation of disulphide bonds [18]. High temperatures occurred also during pasteurization of the initial pea protein isolate. The sum of hydrophobic interactions, hydrogen bonds, and disulphide bonds has also been shown to be responsible for the remarkable stability of whey protein microgels [37].

\section{Intermolecular interactions after microfluidization}

Addition of urea or DTT into the microfluidized insoluble pea protein dispersions neither reduced the particle size any further nor had any major impacts on the turbidity (Table 1). This indicates that microfluidization had disrupted molecular interactions (hydrophobic, hydrogen and disulphide bonds) and chaotropic agents could not further break down protein aggregates.

\section{Molecular disruption mechanism}

Based on our results (Figs. 1-6), Table 1), we propose a disruption mechanism of insoluble pea proteins upon microfluidization as depicted in Fig. 7.

- The hydrophobic interactions as well as hydrogen and disulphide bonds contributed to the stability of the insoluble pea protein aggregates before microfluidization, which is why the solubility was low.

- As the net charges of the insoluble pea proteins did not change upon microfluidization, we conclude that electrostatic interactions were not affected by microfluidization. It should be noted that at $\mathrm{pH} 7$ some positively charged patches on the protein's surface may be bound to the predominantly negatively charged proteins, and thus may have supported the aggregate stabilization to a minor extent before microfluidization.

- Hydrophobic interactions contributed to stabilization of the insoluble pea protein aggregates. High pressures are known to disrupt hydrophobic interactions due to a large volume change upon their formation [38].

- Hydrogen bonds were also shown to stabilize the insoluble pea protein aggregates, although they have been
Table 1 Influence of chaotropic agents (urea and dithiothreitol DTT) on particle size $\left(d_{32}, d_{43}\right)$ and turbidity $\mathrm{T}$ of insoluble pea proteins $(5 \% \mathrm{w} / \mathrm{w}, \mathrm{pH} 7)$ before and after microfluidization (50 MPa for 3 cycles)

\begin{tabular}{llccc}
\hline Treatment & $\mathrm{P}(\mathrm{MPa}) / \mathrm{cycles}$ & $d_{32}(\mu \mathrm{m})$ & $d_{43}(\mu \mathrm{m})$ & $\mathrm{T}\left(\mathrm{cm}^{-1}\right)$ \\
\hline Control $^{\mathrm{a}}$ & $0 \mathrm{MPa}$ & $72.7 \pm 11.2 \mathrm{a}$ & $179.8 \pm 39.0 \mathrm{a}$ & $1.80 \pm 0.40 \mathrm{c}$ \\
& $50 \mathrm{MPa} / 3 \times$ & $0.17 \pm 0.02 \mathrm{~d}$ & $1.1 \pm 0.5 \mathrm{c}$ & $0.95 \pm 0.10 \mathrm{~d}$ \\
$5 \mathrm{M}$ urea & $0 \mathrm{MPa}$ & $59.3 \pm 3.0 \mathrm{~b}$ & $103.9 \pm 5.8 \mathrm{~b}$ & $2.11 \pm 0.10 \mathrm{~b}$ \\
& $50 \mathrm{MPa} / 3 \times$ & $0.18 \pm 0.02 \mathrm{~d}$ & $6.6 \pm 3.7 \mathrm{c}$ & $0.62 \pm 0.03 \mathrm{e}$ \\
$10 \mathrm{mM} \mathrm{DTT}$ & $0 \mathrm{MPa}$ & $43.1 \pm 5.5 \mathrm{c}$ & $93.5 \pm 19.1 \mathrm{~b}$ & $2.80 \pm 0.44 \mathrm{a}$ \\
& $50 \mathrm{MPa} / 3 \times$ & $0.16 \pm 0.01 \mathrm{~d}$ & $13.5 \pm 5.0 \mathrm{c}$ & $0.86 \pm 0.02 \mathrm{~d}, \mathrm{e}$ \\
\hline
\end{tabular}

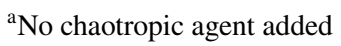

Values within each column followed by different letters denote a statistical difference $(p<0.05)$ 


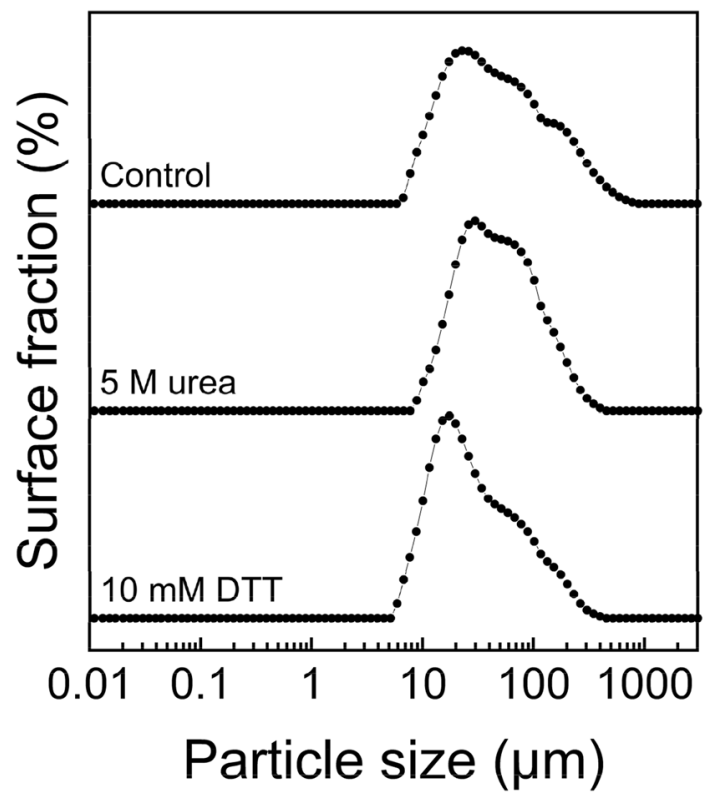

Fig. 6 Particle size $\left(d_{32}\right)$ distribution of aqueous insoluble pea proteins $(5 \% \mathrm{w} / \mathrm{w}, \mathrm{pH} 7)$ after addition of chaotropic agents urea and DTT. Control refers to a sample without addition of chaotropic agent reported to be insensitive to pressures [38]. However, other actions during microfluidization such as turbulence, shear forces, and collisions might have disrupted them.

- Disulphide bonds stabilized the insoluble pea protein aggregates to a large extent and were affected by the microfluidization treatment. Disulphide bonds have been reported to contribute as intramolecular bonds stabilizing subunits of legumin [39].

- Overall, microfluidization was shown to disrupt proteinprotein interactions in insoluble pea protein aggregates leading to smaller particles and increased solubility.

\section{Conclusions}

This study showed that insoluble pea protein aggregates were stabilized via disulphide bonds, hydrogen bonds and hydrophobic interactions. Higher microfluidization pressures and number of applied microfluidization cycles increasingly weakened these interactions between the insoluble pea protein aggregates leading to reductions in particle sizes and

\section{Non-microfluidized}

\section{Microfluidized}

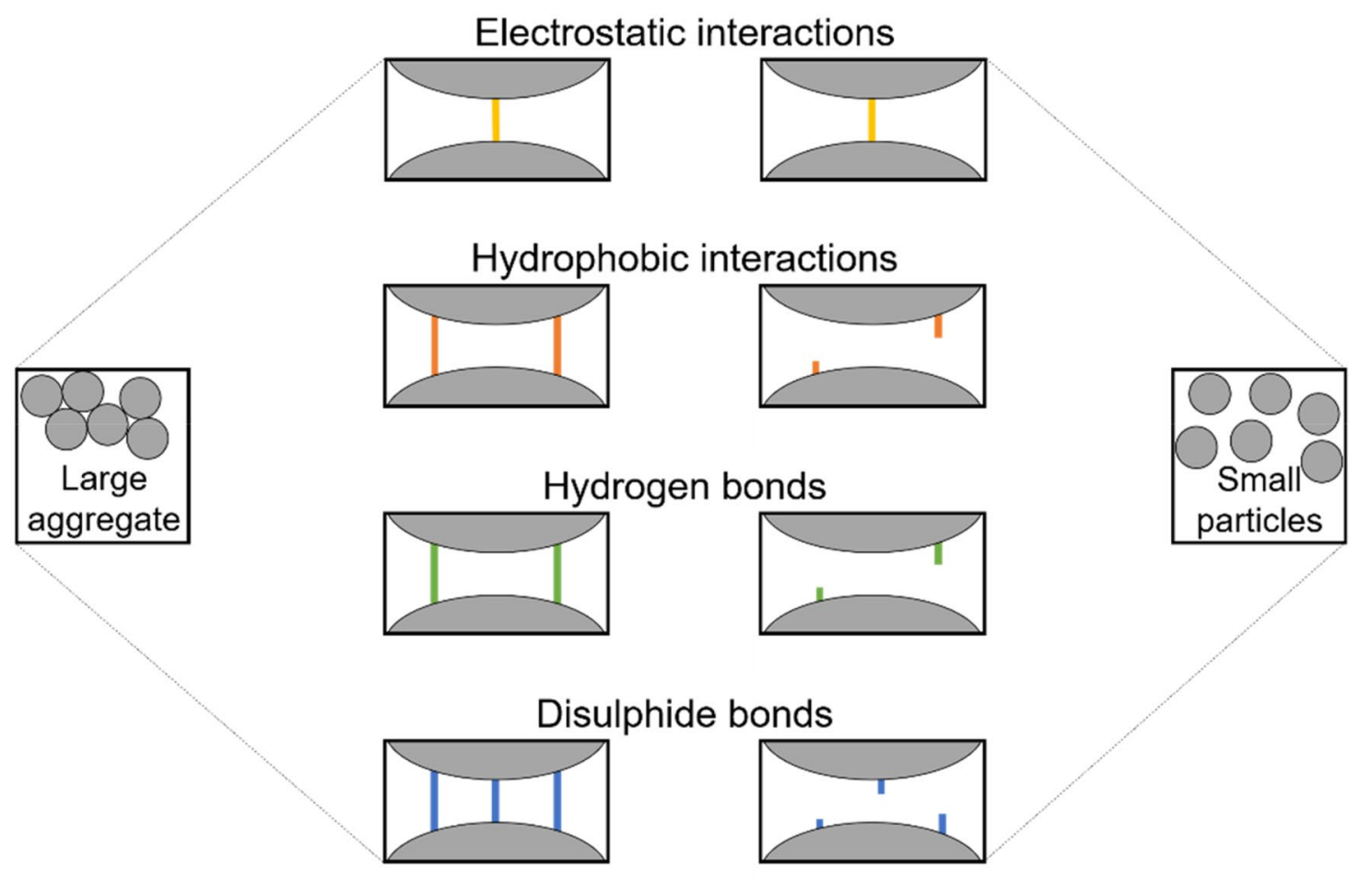

Fig. 7 Proposed molecular disruption mechanism of insoluble pea protein aggregates through microfluidization 
subsequent increases in protein solubility. Therefore, highpressure homogenization as a commercially widely available non-chemical treatment was shown to be a useful method to modify the structure of the insoluble pea proteins. Such modification of the protein structure is of key importance in formulating plant-based protein applications in the food industry. Research on the techno-functional properties of the microfluidized insoluble pea proteins are currently underway.

Author contributions P. M: conceptualization, investigation, formal analysis, visualization, writing - original draft. H. S: conceptualization, writing - original draft, writing_review and editing, project administration. C. S: conceptualization, writing - review and editing, funding. J. W: conceptualization, writing-review and editing, resources, supervision

Funding Open Access funding enabled and organized by Projekt DEAL. This research was funded by Société des Produits Nestlé S.A. (Lausanne, Switzerland)

\section{Compliance with ethical standards}

Conflict of interest The authors declare no conflict of interest.

Compliance with ethics requirements This article does not contain any studies with human or animal subjects.

Open Access This article is licensed under a Creative Commons Attribution 4.0 International License, which permits use, sharing, adaptation, distribution and reproduction in any medium or format, as long as you give appropriate credit to the original author(s) and the source, provide a link to the Creative Commons licence, and indicate if changes were made. The images or other third party material in this article are included in the article's Creative Commons licence, unless indicated otherwise in a credit line to the material. If material is not included in the article's Creative Commons licence and your intended use is not permitted by statutory regulation or exceeds the permitted use, you will need to obtain permission directly from the copyright holder. To view a copy of this licence, visit http://creativecommons.org/licenses/by/4.0/.

\section{References}

1. Lam ACY, Can Karaca A, Tyler RT, Nickerson MT (2018) Pea protein isolates: Structure, extraction, and functionality. Food Rev Int 34:126-147

2. Owusu-Ansah YJ, McCurdy SM (1991) Pea proteins: A review of chemistry, technology of production, and utilization. Food Rev Int 7:103-134. https://doi.org/10.1080/87559129109540903

3. Shevkani K, Singh N, Kaur A, Rana JC (2015) Structural and functional characterization of kidney bean and field pea protein isolates: a comparative study. Food Hydrocoll 43:679-689. https ://doi.org/10.1016/j.foodhyd.2014.07.024

4. Barać MB, Pešić MB, Stanojević SP et al (2015) Techno-functional properties of pea (Pisum sativum) protein isolates-a review. Acta Period Technol 46:1-18. https://doi.org/10.2298/APT15 46001B

5. Alves AC, Tavares GM (2019) Mixing animal and plant proteins: Is this a way to improve protein techno-functionalities?
Food Hydrocoll 97:105171. https://doi.org/10.1016/j.foodh yd.2019.06.016

6. Fuhrmeister H, Meuser F (2003) Impact of processing on functional properties of protein products from wrinkled peas. J Food Eng 56:119-129. https://doi.org/10.1016/S0260-8774(02)00241 $-8$

7. Oliete B, Yassine SA, Cases E, Saurel R (2019) Drying method determines the structure and the solubility of microfluidized pea globulin aggregates. Food Res Int 119:444-454. https://doi. org/10.1016/j.foodres.2019.02.015

8. Zamora A, Guamis B (2015) Opportunities for ultra-high-pressure homogenisation (UHPH) for the food industry. Food Eng Rev 7:130-142. https://doi.org/10.1007/s12393-014-9097-4

9. Dumay E, Chevalier-Lucia D, Picart-Palmade L et al (2013) Technological aspects and potential applications of (ultra) high-pressure homogenisation. Trends Food Sci Technol 31:13-26. https ://doi.org/10.1016/j.tifs.2012.03.005

10. Rayner M, Dejmek P (2015) Engineering aspects of food emulsification and homogenization. CRC Press, Boca Raton, USA

11. Bader S, Bez J, Eisner P (2011) Can protein functionalities be enhanced by high-pressure homogenization?: a study on functional properties of lupin proteins. Procedia Food Sci 1:13591366. https://doi.org/10.1016/j.profoo.2011.09.201

12. Panozzo A, Manzocco L, Calligaris S et al (2014) Effect of high pressure homogenisation on microbial inactivation, protein structure and functionality of egg white. Food Res Int 62:718725. https://doi.org/10.1016/j.foodres.2014.04.051

13. Wu H, Xiao D, Lu J et al (2020) Effect of high-pressure homogenization on microstructure and properties of pomelo peel flour film-forming dispersions and their resultant films. Food Hydrocoll 102:105628. https://doi.org/10.1016/j.foodhyd.2019.10562 8

14. Qamar S, Bhandari B, Prakash S (2019) Effect of different homogenisation methods and UHT processing on the stability of pea protein emulsion. Food Res Int 116:1374-1385. https:// doi.org/10.1016/j.foodres.2018.10.028

15. Djemaoune Y, Cases E, Saurel R (2019) The effect of highpressure microfluidization treatment on the foaming properties of pea albumin aggregates. J Food Sci 84:2242-2249. https:// doi.org/10.1111/1750-3841.14734

16. Bałdyga J, Orciuch W, Makowski $Ł$ et al (2007) Break up of nano-particle clusters in high-shear devices. Chem Eng Process 46:851-861. https://doi.org/10.1016/j.cep.2007.05.016

17. Kessel A, Ben-Tal N (2018) Introduction to proteins: structure, function, and motion, 2nd edn. CRC Press, Boca Raton, USA

18. Visschers RW, De Jongh HHJ (2005) Bisulphide bond formation in food protein aggregation and gelation. Biotechnol Adv 23:75-80. https://doi.org/10.1016/j.biotechadv.2004.09.005

19. Masson P (1993) Effects of high pressure on proteins. Food Rev Int 9:611-628. https://doi.org/10.1080/87559129309540980

20. Messens W, Van Camp J, Huyghebaert A (1997) The use of high pressure to modify the functionality of food proteins. Trends Food Sci Technol 8:107-112. https://doi.org/10.1016/S0924 -2244(97)01015-7

21. BVL (2011) Amtliche Sammlung von Untersuchungsverfahren nach § 64 LFGB, § 35 vorläufiges Tabakgesetz, § 28b GenTG: Verfahren zur Probenahme und Untersuchung von Lebensmitteln. Beuth Verlag, Berlin

22. Dumas JBA (1831) Procédés de l'analyse organique. Ann Chim Phys 247:198-213

23. Mariotti F, Tomé D, Mirand PP (2008) Converting nitrogen into protein: beyond 6.25 and Jones' factors. Crit Rev Food Sci Nutr 48:177-184. https://doi.org/10.1080/10408390701279749

24. Gao Z, Shen P, Lan Y et al (2020) Effect of alkaline extraction $\mathrm{pH}$ on structure properties, solubility, and beany flavor of 
yellow pea protein isolate. Food Res Int 131:109045. https://doi. org/10.1016/j.foodres.2020.109045

25. Colonna P, Gallant D, Mercier C (1980) Pisum sativum and Vicia faber carbohydates: studies of fractions obtained after dry and wet protein extraction process. J Food Sci 45:1629-1639. https://doi. org/10.1111/j.1365-2621.1980.tb07578.x

26. Gutöhrlein F, Drusch S, Schalow S (2020) Extraction of low methoxylated pectin from pea hulls via RSM. Food Hydrocoll. https:// doi.org/10.1016/j.foodhyd.2019.105609

27. Yang J, Liu G, Zeng H, Chen L (2018) Effects of high pressure homogenization on faba bean protein aggregation in relation to solubility and interfacial properties. Food Hydrocoll 83:275-286. https://doi.org/10.1016/j.foodhyd.2018.05.020

28. Song X, Zhou C, Fu F et al (2013) Effect of high-pressure homogenization on particle size and film properties of soy protein isolate. Ind Crops Prod 43:538-544. https://doi.org/10.1016/j.inder op.2012.08.005

29. Mirhosseini H, Tan CP, Hamid NSA, Yusof S (2008) Optimization of the contents of arabic gum, xanthan gum and orange oil affecting turbidity, average particle size, polydispersity index and density in orange beverage emulsion. Food Hydrocoll 22:1212-1223. https://doi.org/10.1016/j.foodhyd.2007.06.011

30. Kleizen HH, de Putter AB, van der Beek M, Huynink SJ (1995) Particle concentration, size and turbidity. Filtr Sep 32:897-901. https://doi.org/10.1016/S0015-1882(97)84175-4

31. Chen X, Xu X, Zhou G (2016) Potential of high pressure homogenization to solubilize chicken breast myofibrillar proteins in water. Innov Food Sci Emerg Technol 33:170-179. https://doi. org/10.1016/j.ifset.2015.11.012

32. Liu HH, Kuo MI (2016) Ultra high pressure homogenization effect on the proteins in soy flour. Food Hydrocoll 52:741-748. https:// doi.org/10.1016/j.foodhyd.2015.08.018

33. Sun XD, Arntfield SD (2012) Molecular forces involved in heat-induced pea protein gelation: effects of various reagents on the rheological properties of salt-extracted pea protein gels. Food Hydrocoll 28:325-332. https://doi.org/10.1016/j.foodh yd.2011.12.014

34. Grossmann L, Wörner V, Hinrichs J, Weiss J (2019) Mechanism of the formation of insoluble structures in a protein extract of the microalga Chlorella protothecoides at $\mathrm{pH}$ 3. Food Biosci 28:140 142. https://doi.org/10.1016/j.fbio.2019.01.020

35. Feyzi S, Milani E, Golimovahhed QA (2018) Grass pea (Lathyrus sativus L.) protein isolate: the effect of extraction optimization and drying methods on the structure and functional properties. Food Hydrocoll 74:187-196. https://doi.org/10.1016/j.foodh yd.2017.07.031

36. Osen R, Toelstede S, Eisner P, Schweiggert-Weisz U (2015) Effect of high moisture extrusion cooking on protein-protein interactions of pea (Pisum sativum L.) protein isolates. Int J Food Sci Technol 50:1390-1396. https://doi.org/10.1111/ijfs.12783

37. Schmitt C, Moitzi C, Bovay $C$ et al (2010) Internal structure and colloidal behaviour of covalent whey protein microgels obtained by heat treatment. Soft Matter 6:4876-4884. https://doi. org/10.1039/c0sm00220h

38. Galazka VB, Dickinson E, Ledward DA (2000) Influence of high pressure processing on protein solutions and emulsions. Curr Opin Colloid Interface Sci 5:182-187. https://doi.org/10.1016/S1359 -0294(00)00055-8

39. Matta NK, Gatehouse JA, Boulter D (1981) Molecular and subunit heterogeneity of legumin of Pisum sativum L. (garden pea)- a multi-dimensional gel electrophoretic study. J Exp Bot 32:12951307. https://doi.org/10.1093/jxb/32.6.1295

Publisher's Note Springer Nature remains neutral with regard to jurisdictional claims in published maps and institutional affiliations. 